Fall 2007

\title{
Seven perceptions influencing novice teachers' efficacy and cultural competence
}

Nancy P. Gallavan

University of Central Arkansas

Follow this and additional works at: https://digitalscholarship.unlv.edu/jpme

\section{Repository Citation}

Gallavan, Nancy P. (2007) "Seven perceptions influencing novice teachers' efficacy and cultural competence," Journal of Praxis in Multicultural Education: Vol. 2: No. 1, Article 1.

DOI: 10.9741/2161-2978.1020

Available at: https://digitalscholarship.unlv.edu/jpme/vol2/iss1/1

This Article is protected by copyright and/or related rights. It has been brought to you by Digital Scholarship@UNLV with permission from the rights-holder(s). You are free to use this Article in any way that is permitted by the copyright and related rights legislation that applies to your use. For other uses you need to obtain permission from the rights-holder(s) directly, unless additional rights are indicated by a Creative Commons license in the record and/ or on the work itself.

This Article has been accepted for inclusion in Journal of Praxis in Multicultural Education by an authorized administrator of Digital Scholarship@UNLV. For more information, please contact digitalscholarship@unlv.edu. 


\title{
Seven Perceptions Influencing Novice Teachers' Efficacy and Cultural Competence
}

\begin{abstract}
Nancy P. Gallavan
Novice teachers believe and behave according to perceptions about teaching, learning, and schooling they formed during childhood and adult experiences with families, classrooms, communities, media, and teacher education programs. Perceptions build funds of knowledge shaping teacher efficacy that influence their development of cultural competence-the processes of acquiring, accepting, and applying requisite knowledge, skills, and dispositions for ensuring educational equity and excellence for all learners. Through their words, actions, and interactions, novice teachers socially reproduce their interpretations of perceptions influencing their cultural competence visible through their generational perpetuation of practice.

Survey research with novice teachers reveals the importance of their critical thinking substantiated with novice teachers' benefits and limitations for each perception. Implications for personal, professional, and pedagogical growth are supported by novice teachers' voices.
\end{abstract}

Teacher efficacy encapsulates the single most important variable related to learner achievement (Darling-Hammond, 1997). Defined by Tschannen-Moran, Woolfolk Hoy, and Hoy (1998), teacher efficacy involves "the teacher's belief in his or her capability to organize and execute courses of action required to successfully accomplish a specific teaching task in a particular context" (p. 223). Although each teacher candidate brings individual attributes that contribute to shaping one's professional identity (Beijaard, Verloop, \& Vermunt, 1999), teacher education programs certainly play a vital role in molding teacher efficacy.

The United States needs more teachers and teachers who demonstrate a greater sense of efficacy to increase learner achievement. In 1996, the National Commission on Teaching and America's Future reported that teacher education programs across the U.S. experience a $75 \%$ attrition rate among teacher candidates or novices entering their undergraduate programs and progressing

Nancy P. Gallavan, Ph.D., is Associate Dean of the College of Education and a professor at the University of Central Arkansas. She specializes in social studies and multicultural education. She has authored more than 60 journal articles, book chapters, and books. With Ellen Kottler, Nancy has authored Secrets to Success for Beginning Elementary School Teachers and Secrets to Success for Social Studies Teachers. 
through the third year of their teaching careers. Additionally, $17 \%$ of all novice classroom teachers leave their positions within the first three years of teaching (U.S. Department of Education, 1997).

Novice teachers-teacher candidates and classroom teachers in their first three years of teaching - who exhibit a greater sense of efficacy are more likely to reap greater career satisfaction (Krumboltz, 1994) and persist, staying longer in their teacher education programs and teaching careers (Knobloch \& Whittington, 2002). Corresponding directly with teacher growth (Smylie, 1998), teachers enhance their efficacy by building upon prior knowledge and experiences, gaining new information and insights, and, ultimately, filtering and interpreting phenomena and perceptions (Richardson \& Placier, 2001) that, hopefully, contribute positively and productively to their classroom interactions and career satisfaction.

Teacher efficacy stems from lifelong experiences resulting in teacher beliefs and perceptions affecting how teachers see themselves individually and collectively. Beliefs have been defined as "all the matters of which we have no sure knowledge and yet which we are sufficiently confident to act upon and all the matters that we now accept as certainly true, as knowledge, but which nevertheless may be questioned in the future" (Dewey, 1933, p.6). However, few educators, especially novice teachers, question their beliefs and perceptions; most educators tend to view their beliefs or perceptions as the commonly assumed and shared ways of believing and acting.

As novice teachers progress through their teacher education programs and initiate their teaching careers, they begin growing personally, professionally, and pedagogically (Gallavan, 2005) by expanding upon their beliefs and perceptions about themselves as individuals, educators in general, and teachers in classrooms. Their growth in all three areas influences their development of cultural competence - the processes of accepting, acquiring, and applying requisite knowledge, skills, and dispositions for ensuring educational equity and excellence for all learners. Reflected by their words, actions, and interactions, novice teachers establish funds of knowledge and socially reproduce their cultural competence through their generational perpetuation of practice.

From work in schools and classrooms, seven beliefs or perceptions have been identified that teachers use and rely upon during their interactions with P-12th grade students and novice teachers. All seven perceptions have been incorporated, seemingly without challenge, into teaching, learning, and schooling for many years. In this research, each perception is described and accompanied by benefits and limitations voiced by novice teachers that influence their efficacy and development of cultural competence. Novice teachers' responses reveal the importance of critical thinking about their assumed beliefs illustrated by the implications for personal, professional, and pedagogical growth. 


\section{Advancing Teacher Efficacy with Valuing Diversity}

For teacher educators to transform teacher education (Causey, Thomas, \& Armento, 1999) so that it enhances teacher efficacy (and thus teacher satisfaction and career retention), teacher educators must ensure that all novice teachers become proficient in valuing cultural diversity during their university courses and field experiences. Valuing cultural diversity for novice teachers encompasses:

- Curricular Content: in-depth information from multiple viewpoints with historical and contemporary perspectives about our interdependent, multicultural, international, and global society taught directly, indirectly, and integrated across the curriculum;

- Instructional Processes: assorted approaches and established strategies to teaching, learning, assessments, and schooling incorporated naturally, authentically, and holistically;

- Educational Context: relevant balance of individual, shared, and cooperative experience where all students learn about themselves, one another, and all of society;

- Academic Scholarship: concerted focus on engagement, expression, and achievement where all students highlight their strengths and interests while simultaneously all students nurture their weaknesses and awareness;

- Community Service: meaningful connections with other individuals in classrooms, schools, and communities to provide all students with information, access, and opportunity (Gallavan, 2005) to learn, contribute, and achieve while assisting others as well as themselves;

- Preparational Experience: multiple opportunities for novice teachers to interact realistically with diverse populations of students, teachers, and environments where cultural competence is understood, practiced, and promoted; and

- Self Reflection: continued observation and assessment of one's beliefs and behaviors to prompt growth and development.

Teacher efficacy that values cultural diversity advances when synchronized with three factors: (1) building funds of knowledge, (2) developing cultural competence, and (3) realizing the significance of social reproduction or generational perpetuation of practice. 


\section{Building Funds of Knowledge}

All novice teachers bring funds of knowledge (Moll \& Gonzáles, 2004) with them to their own teaching. Novice teachers' funds are drawn from childhood and adult experiences in their homes, classrooms, communities, media, and teacher education programs. We know that many novice teachers pursue careers in education because they liked school, were successful as students, and could visualize themselves as teachers.

Novice teachers construct their funds of knowledge from both internal and external stimuli. Internal funds of knowledge extend from experiences inside or near an environment. For example, novice teachers whose own parents are classroom teachers or school administrators or novice teachers who were more successful academically appear to have greater insight or social capital for enhancing their teacher efficacy. Most likely, these novice teachers tend to look like and act like most teachers and successful students, increasing their personal and professional identification with being a teacher.

External funds of knowledge are gleaned from outside an environment. For example, novice teachers who have not had experiences with particular grade levels, subject areas, types of learners, or parts of town (country or world), would need to build upon their social capital to bolster their teacher efficacy. Most likely, these novice teachers either do not look like or act like most teachers or other successful students. These novice teachers are limited in their personal and professional identification with being a teacher in this particular context.

Both kinds of novice teachers would grow significantly from teacher education and experiences that build upon their internal and external funds of knowledge to enhance their teacher efficacy.

\section{Developing Cultural Competence}

The process of developing cultural competence entails acknowledging the existence and honoring the importance of culture in the broadest definition-one that includes every way of describing and possibly identifying or grouping individuals either temporarily or permanently. The process of developing cultural competence involves incorporating awareness of and sensitivity to our own thoughts, words, actions, and interactions related to culture in both formal and informal settings and expressions from other individuals. The process does not permit selectivity of times and places when one can or cannot demonstrate cultural competence.

Developing cultural competence means conducting an honest assessment of cross-cultural relations from one's individual venue as well as 
analyzing an objective evaluation of the world from multiple viewpoints regardless of one's support of the outcomes. It does not allow for seeing or believing only what one wants to see or believe.

The process of developing cultural competence also means maintaining a vigilant cognizance of dynamics associated with thinking critically and negotiating cognitive dissonance (McFalls \& Cobb-Roberts, 2001). One must preserve an intellectual rather than an emotional demeanor especially when engaging in "critical, dialogical, and self-reflexive" tensions (Asher, 2007, 71). Novice teachers must expand their capacities related to practicing cultural selfawareness, the ability to understand one's own sociocultural context, and the willingness to accept explanations for similarities and differences within and across groups (Ward \& Ward, 2003).

For novice teachers, developing cultural competence entails building personal, professional, and pedagogical funds of knowledge. That means, novice teachers grow by recognizing and supporting their growth as individuals, career educators, and experts in the classroom teaching their students as a whole group while meeting each student's unique needs. The field of cultural competence recognizes the inherent challenges for teachers to disentangle cultural competence from social factors frequently intensified and exasperated by other teachers, society, or the media. Novice teachers must work within the social context to ensure success for all learners (Betancourt, Green, Carrillo, \& Ananeh-Firempong, 2003).

\section{Realizing the Significance of Social Reproduction}

The third factor contributing to teacher efficacy is realizing the significance of social reproduction (Demaine, 2003; Farber, Wilson, \& Holm, 1989). This is a sociological concept when, "over time, groups of people, notably social classes, reproduce their own social structures and patterns" (Bilton et. al, 1996, p. 670) reflective of their beliefs and perceptions. Schools and teachers have set specific academic standards and personal qualities that they teach and reward. Social reproduction means that established expectations, based on tradition and need, are conveyed to constituents through both direct and indirect mechanisms to inform and control a population.

Two types of social reproduction pertain particularly to developing cultural competence: conservative and progressive. Conservative social reproduction promotes the status quo; in schools and classrooms, the teaching and learning tend to continue as they always have. Expectations, visible through the available information, access, and opportunities, usually do not differ to accommodate anyone's cultural characteristics or individual needs and preferences. 
Progressive social reproduction advocates reform; in schools and classrooms, teaching and learning are open to agents of change. Expectations are written collaboratively and communicated transparently to promote democratic principles and social justice that are fair and equitable for all learners. When teacher efficacy and cultural diversity have been incorporated into teacher education, novice teachers are empowered to become agents of change (Gerwirtz \& Cribb, 2003), to take charge of their own growth (Ghaith \& Shaaban, 1999), and to develop cultural competence. As novice teachers become classroom mentor teachers working with P-12th grade students (as well as future novice teachers), novice teachers continue the generational perpetuation of practice.

\section{Identifying Seven Perceptions}

Seven perceptions were identified as general statements that teacher educators frequently hear from novice teachers, found in educational literature, and repeated as established funds of knowledge maintained through conservative and progressive social reproduction. Each perception is communicated and reinforced both overtly and covertly through a multitude of messages, methods, models, mentoring, and meanings (Gallavan, Putney, \& Brantley, 2002) to novice teachers. The seven perceptions selected for this study include:

1. Teachers want and tend to teach the ways they were taught.

2. Teachers want to teach near their homes or in neighborhoods like their own or the neighborhoods where they were raised.

3. Teachers want to teach students like their own children or the children they knew growing up.

4. Teachers want to teach students who cooperate and behave in ways that are similar to ways the teacher behaves.

5. Teachers want to teach students who achieve and who express their learning in ways similar to ways the teacher expresses learning.

6. Teachers do not want to teach topics and issues associated with multicultural education.

7. Teachers do not want the responsibility of ensuring equity for all children in their classrooms and schools. 


\section{Conducting the Study}

The purpose of the study was to examine novice teachers' beliefs (Delandshere \& Jones, 1999) and personal practice knowledge (Connelly \& Clandinin, 2004) influencing the development of their cultural competence. Teachers tend to resist change (Richardson \& Placier, 2001), so responses from novice teachers most likely reflect the beliefs and behaviors communicated to them.

A survey with 12 statements was constructed (see Appendix I.) Section I contained the first five perceptions to which respondents provided a benefit and a limitation associated with each of the perceptions. Section II included Perceptions 6 and 7 to which respondents provided only a reaction. The survey was administered near the end of the semester to 65 novice teachers of grades P12 with less than three years of teaching experience enrolled in one of three graduate multicultural education courses at one mid-western university.

\section{Examining the Findings}

Data from 62 usable surveys were tabulated and grouped according to perception. In response to the request to mark the perceptions that describe the respondent, novice teachers reported the results found in Table 1 . The novice teachers participating in this research overwhelmingly describe themselves with these seven perceptions.

A synthesis of responses to statements 1 through 5 grouped as Benefits and Limitations for each perception follows.

\section{Perception 1. Teachers want and tend to teach the ways they were taught.}

1-A. Benefits: Novice teachers are eager to replicate their own childhood teachers. While enrolled in their teacher education programs, they learn the most about teaching from their classroom mentors and field teaching experiences. In relationship to cultural competence, novice teachers reported that some university professors and classroom teachers emphasize valuing cultural diversity. One novice teacher wrote, "I always wanted to be just like my thirdgrade teacher; my goal is to teach in the same school."

1-B. Limitations: However, many novice teachers did not experience effective teaching and learning that they want to replicate. Many of them did not grow up in culturally diverse environments or attend schools where diversity was valued. Many novice teachers did not observe or participate in cultural 


\section{Table 1}

Seven Perceptions that Describe Teachers*

\begin{tabular}{ll}
\hline Perception & $\begin{array}{l}\text { Percent of novice teachers } \\
\text { indicating that the perception } \\
\text { describes them }\end{array}$ \\
\hline
\end{tabular}

Perception 1. Teachers want and tend to teach the ways they were taught.

Perception 2. Teachers want to teach near their homes or in neighborhoods like their own or the neighborhoods where they were raised.

Perception 3. Teachers want to teach students like their own children or the children they knew growing up.

Perception 4. Teachers want to teach students who cooperate and behave in ways that are similar to ways the teacher behaves.

Perception 5. Teachers want to teach students who achieve and who express their learning in ways similar to ways the teacher expresses learning. $\quad 97 \%$

Perception 6. Teachers do not want to teach topics and issues associated with multicultural education.

Perception 7. Teachers do not want the responsibility of ensuring equity for all students in their classrooms and schools.

\footnotetext{
*Novice teachers include teacher candidates and teachers through the first three years of teaching.
} 
competence during their field experiences. "I thought the classroom mentor teacher was prejudiced against some of the students."

Perception 2. Teachers want to teach near their homes or in neighborhoods like their own or the neighborhoods where they were raised.

2-A. Benefits: Like most workers, novice teachers prefer a short commute to save time, money, and energy. Teaching near their homes provides familiarity and a sense of safety with the neighborhood, local people, businesses, and resources. Novice teachers feel like they share the same qualities of life when teaching in their own or similar neighborhoods. In relationship to cultural competence, some novice teachers are aware of and can promote the cultural diversity that exists within their own neighborhoods. "If I teach near my home, I can stay later and be more involved in the after school programs and activities."

2-B. Limitations: Not all neighborhoods have enough teachers living in them so teachers, often novice teachers, are assigned to neighborhoods where fewer teachers live. Novice teachers do not feel safe or welcome in all neighborhoods; their families do not want them to be in certain neighborhoods, particularly after dark. "It seems to me that first-year teachers are assigned to jobs in the less desired schools and parts of town since the veteran teachers can transfer to the more desired schools and neighborhoods."

Perception 3. Teachers want to teach students like their own children or the children they knew growing up.

3-A. Benefits: Most novice teachers feel more comfortable and successful teaching students like their own children. They can communicate easily with these students and share similar references to connect learning to the world. Teaching students like their own children or like themselves fulfills novice teachers' goals for becoming a teacher. In relationship to cultural competence, teachers and students may be able to communicate more clearly with shared backgrounds to introduce topics and issues of multicultural education. "I seem to know intrinsically what my own children want and need."

3-B. Limitations: Not all students are like teachers' children. Many children live in homes or neighborhoods with much different families, customs, traditions, and lifestyles. Teachers cannot be selective about who they teach; teachers cannot show preferential treatment for their own. All teachers need to understand and accept all students to help them to achieve. "Who is going to teach children of color if we have so few teachers of color?" 
Perception 4. Teachers want to teach students who cooperate and behave in ways that are similar to ways the teacher behaves.

4-A. Benefits: Every teacher wants to teach students who cooperate and behave. It is the responsibility of the teacher to teach cooperation and to reinforce positive behaviors. The teacher and students can decide classroom expectations together. And, most school administrators distribute students with various kinds of behaviors mindfully across each grade level so all teachers are treated equally. In relationship to cultural competence, students learn more about themselves and one another. "We can cover more curriculums and have more fun when everyone gets along."

4-B. Limitations: Some teachers simply do not give all students an equal chance. Students are challenged in classrooms when they don't do things exactly as the teacher expects. "Routine classroom management is hard enough. I wish more students would show respect like I learned as a child."

Perception 5. Teachers want to teach students who achieve and who express their learning in ways similar to ways the teacher expresses learning.

5-A. Benefits: Teaching is much easier and more rewarding when students grasp new ideas quickly and do their assignments well. Once students master one set of expectations, the teacher can move on to the next set of expectations. In relationship to cultural competence, students can teach one another. "When my students do well, I feel good. Then I teach better too."

5-B. Limitations: Student achievement is a major concern of most teachers. Novice teachers have learned to teach to the test so students express themselves in ways that are tested. The test and teachers' forms of expression may not align with the ways all students express themselves best. "If my success as a teacher depends directly on the achievement of my students, then, naturally, I want to teach students who score high on the tests."

\section{Summarizing the Implications}

The implications of this research are evident in the novice teachers' reactions to perceptions 6 and 7 .

Perception 6: Teachers do not want to teach topics and issues associated with multicultural education.

Reactions: Novice teachers do not know multicultural education content well enough to incorporate it naturally into their curriculum, instruction, and 
assessments. Although they had completed a course in multicultural education, novice teachers tend to avoid multicultural education as much as possible as it seems unsafe and controversial. They certainly do not want to offend anyone, or everyone. Plus, multicultural education is not in the standards or on the test; and there is not enough time to teach what feels like extra content. "I think we all try to do our best. If this really is important to the school, the administration should help us."

Perception 7: Teachers do not want the responsibility of ensuring equity for all students in their classrooms and schools.

Reactions: Novice teachers do not know what equity is, how to ensure equity, or what their responsibility fully entails. It is easier to ignore this charge and hope that someone else takes care of it. There is not enough time, energy, guidance, support, or resources to ensure equity for all students anyway. "I always try to be as fair as I can."

\section{Recommending Changes}

Historically, novice teachers have eagerly adopted and reflected the seven perceptions of teaching examined in this research. By ignoring or avoiding diversity among their learners, about their learners, or by their learners (Gallavan, 1998), they have created a singleness or uniformity of outcomes evident in the current curriculum, instruction, assessments, as well as educator workforce.

Moll and Gonzáles (2003, p. 699) translate Ferreiro (1994) as suggesting "that the great challenge for the future of schooling is how to transform diversity into a pedagogical asset." Novice teachers should experience change and transformation during their teacher education courses as novice teachers will not change once they have begun their careers (Nettle, 1998; Richardson \& Placier, 2001). We know that schools serve as the "cultural transmitters" (p. 359) "cultural mediators" (p. 360) and "cultural transformers" (p. 361) of U.S. society (Cockrell, Placier, Cockrell, \& Middleton, 1999), so novice teachers must be guided and supported in developing cultural competence.

From this research, seven changes are recommended for teacher education, induction, and professional development programs for classroom teachers to support novice teachers in enhancing teacher efficacy and developing cultural competence: 
1. all courses throughout the professional education unit adhere to a set of cultural diversity proficiencies evident in the content, practices, and context of each course (Pohan, 1996);

2. all field experiences incorporated into the teacher education program include placements that adhere to the same set of cultural diversity proficiencies with mentors who model genuine cultural competence (Herrington, Sparrow, Herrington, \& Oliver, 1999);

3. all teacher candidates are required to successfully complete a course dedicated exclusively to valuing cultural diversity (a.k.a., multicultural education) exploring knowledge, skills, and dispositions taught by professors to develop cultural competence (Leonard \& Leonard, 2005);

4. all first- and second-year teachers are required to participate in an induction program that provides teachers with school time, frequent opportunities, and multiple resources to talk with and observe experienced teachers, school administrators, and other novice teachers to develop cultural competence (Gilbert, 2005);

5. all first- and second-year teachers will be assigned a mentor in their school buildings with whom they can talk, observe, and participate in peer coaching, action research, and pressure relief (Wlodkowski, 2003);

6. all classroom teachers will be guided in the processes of mentoring novice teachers especially in areas related to developing cultural competence (Ward \& Ward, 2003); and

7. all classroom mentor teachers will be provided school time, frequent opportunities, and multiple resources to develop cultural competence while reducing their cognitive dissonance and resistance to diversity (McFalls \& Cobb-Roberts, 2001), and improve their own efficacy and mentoring.

Novice teachers must be sure they want to teach in today's world, and they want to teach an ever-changing diverse population of students with varying learning styles, needs, and cultural backgrounds (Logan, 1996). Novice teachers need to understand and want to teach content and processes related to democratic principles, human rights, and social justice to ensure educational equity and excellence for all learners (Causey, Thomas, \& Armento, 1999; Garmen, 2004). For the sake of their students and work with future novice teachers (Ming \& Dukes, 2006), novice teachers must be helped in acknowledging and adjusting their perceptions (Richards, 2002) that influence their cultural competence, visible through their generational perpetuation of practice. To achieve these outcomes, teacher educators must act deliberately so 
cultural competence plays a prominent role throughout their teacher education programs (Gay \& Howard, 2000).

\section{References}

Asher, N. (2007). Made in the (multicultural) USA: Unpacking tensions of race, culture, gender, and sexuality in education. Educational Researcher, 36(2), 65-73.

Beijaard, D., Verloop, N., \& Vermunt, J. D. (1999). Teachers' perceptions of a professional identity: An exploratory study from a personal knowledge perspective. Teaching and Teacher Education, 16(2000), 749-764.

Betancourt, J. R., Green, A. R., Carrillo, J. E., \& Ananeh-Firempong, II, O. (2003). Defining cultural competence: A practical framework for addressing racialethnic disparities in health and health care. Public Health Reports, 118, 293302.

Bilton, T., Bonnett, K. Jones, P., Lawson, T., Skinner, D., Stanworth, M., \& Webster, A. (1996). Introductory Sociology, (3rd ed.). London: Macmillan.

Causey, V. E., Thomas, C. D., \& Armento, B. J. (1999). Cultural diversity is basically a foreign term to me: The challenges of diversity for preservice teacher education. Teaching and Teacher Education, 16(2000), 33-45.

Clandinin, D. J., \& Connelly, F. M. (2000). Narrative inquiry: Experience and story in qualitative research. San Francisco: Jossey-Bass Publishers.

Cockrell, K. S., Placier, P. L., Cockrell, D. H., \& Middleton, J. H. (1999). Coming to terms with "diversity" and "multiculturalism" in teacher education: Learning about our students, changing our practice. Teaching and Teacher Education, 15(1999), 351-366,

Darling-Hammond, L. (1997). Doing what matters most: Investing in quality teaching. New York: National Commission on Teaching and America's Future.

Delandshire, G., \& Jones, J. H. Elementary teachers' beliefs about assessment in mathematics: A case of assessment paralysis. Journal of Curriculum and Supervision, 14(3), 216-240.

Demaine, J. (2003). Social reproduction and education policy. International Studies in Sociology of Education, 13(2), 125-140.

Dewey, J. (1933). How we think. Boston: D. C. Heath.

Farber, P., Wilson, P., \& Holm, G.(1989). From innocence to inquiry: A social reproduction framework. Journal of Teacher Education, 40(1), 45-50.

Gallavan, N. P. (1998). "Why aren't teachers using effective multicultural education practices?" Five major insights from experienced teachers. Equity and Excellence in Education, 31(2), 20-27.

Gallavan, N. P. (2005). Helping teachers unpack their "invisible knapsacks." Multicultural Education. 13(1), 36-39.

Gallavan, N. P., Putney, L. G., \& Brantley, D. K. (2002). The influences of modeling: Elementary school preservice teachers rate their levels of competence and confidence for teaching social studies. Social Studies and the Young Learner, 14(3), 28-30. 
Garmen, M. A. (2004). Changing preservice teachers' attitudes/beliefs about diversity. Journal of Teacher Education, 55(3), 201-213.

Gay, G., \& Howard, T. C. (2000). Multicultural teacher education for the 21st century. The Teacher Educator,36(1), 1-16.

Gerwirtz, S., \& Cribb, A. (2003). Recent readings of social reproduction: Four fundamental problems. International Studies in Sociology of Education, 13(3), 243-260.

Ghaith, G., \& Shaaban, K. (1999). The relationship between perceptions of teaching concerns, teacher efficacy, and selected teacher characteristics. Teaching and Teacher Education, 15(1999), 487-496.

Gilbert, L. (2005). What helps beginning teachers? Educational Leadership, 62(8), 36-39.

Herrington, T., Sparrow, L., Herrington., J., \& Oliver, R. (1999). Investigating mathematics education using multimedia. Journal of Technology and Teacher Education, 7(3), 175-186.

Knobloch, N. A., \& Whittington, M. S. (2002). Novice teachers' perceptions of support, teacher preparation quality, and student teaching experience related to teacher efficacy. Journal of Vocational Educational Research, 27(3), 331-341.

Krumboltz, J. D. (1994). The career beliefs inventory. Journal of Counseling and Development 72, 424-433.

Leonard, P., \& Leonard, L. (2005). Teachers and tolerance: Discriminating diversity dispositions. The Teacher Educator, 42(1), 30-62.

Logan, L. (1996). Want to teach? First go to the mall. Phi Delta Kappa 77, 383-384.

McFalls, E. L., \& Cobb-Roberts, D. (2001). Reducing resistance to diversity through cognitive dissonance instruction. Journal of Teacher Education 52(2), 164-172.

Ming, K., \& Dukes, C. (2006). Fostering cultural competence through school-based routines. Multicultural Education, 14(1), 42-48.

Moll, L, \& Gonzáles, N. (2004). Engaging life: A funds-of-knowledge approach to multicultural education. In J. A. Banks \& C. A. M. Banks (Eds). Handbook of Research on Multicultural Education, (2nd ed.; pp. 699-715). San Francisco: Jossey-Bass.

Nettle, E. B. (1998). Stability and change in the beliefs of student teachers during practice teaching. Teaching and Teacher Education, 14(2), 193-204.

Pohan, C. A. (1996). Preservice teachers' beliefs about diversity: Uncovering factors leading to multicultural responsiveness. Equity and Excellence in Education, 29(3), 62-69.

Richards, J. (2002). Why teachers resist change (and what principals can do about it). Principal 81(4), 75-77.

Richardson, V., \& Placier, P. (2001). Teacher change. In V. Richardson (Ed.), Handbook of research on teaching (4th ed.; pp. 905-950). Washington, DC: American Education Research Association.

Smylie, M. (1988). The enhancement function of staff development: Organizational and psychological antecedents to individual teacher change. American Educational Research Journal, 25(1), 1-30.

Tschannen-Moran, M., Woolfolk Hoy, A., \& Hoy, W. K. (1998). Teacher efficacy: Its meaning and measure. Review of Educational Research, 68, 202-248. 
U.S. Department of Education. (1997). Characteristics of stayers, movers, and leavers: Results from the teacher follow-up survey: 1994-1995. Washington, DC: National Center for Educational Statistics.

Ward, M. J., \& Ward, J. W. (2003). Promoting cross-cultural competencies in preservice teachers through second language use. Education, 123(3), 532-536.

Wlodkowski, R. J., (2003). Fostering motivation in professional development programs. New Directions for Adult and Continuing Education, 98, 39-47. 
Appendix

Survey Examining Seven Perceptions Influencing Teachers' Cultural Competence

Classroom teachers have acquired seven perceptions from various sources throughout their lives that influence them in the classroom and their cultural competence to ensure educational equity and excellence for all learners. We want to know what you think. Please follow the instructions for each section. This survey should take less than 15 minutes to complete. Return your completed survey to the graduate student administering the survey. All information that identifies you will be removed before the researchers read your responses. Thank you in advance for participating in this survey! Your responses will improve our teaching!

Section I. Please write one benefit (positive influence) and one limitation (negative influence) associated with statements 1-5 in relationship to cultural competence. Place a large $\mathrm{X}$ in the left margin next to each perception that describes you.

1. Teachers want and tend to teach the ways they were taught.

1-A. Benefit:

1-B. Limitation:

2. Teachers want to teach near their homes or in neighborhoods like their own or the neighborhoods where they were raised.

2-A. Benefit:

2-B. Limitation:

3. Teachers want to teach students like their own children or children they knew growing up.

3-A. Benefit:

3-B. Limitation:

4. Teachers want to teach students who cooperate and behave in ways that are similar to ways the teacher behaves.

4-A. Benefit:

4-B. Limitation:

5. Teachers want to teach students who achieve and who express their learning in ways similar to ways the teacher expresses learning.

5-A. Benefit:

5-B. Limitation: 
Section II. Please write one reaction to statements $6 \& 7$. Place a large $\mathrm{X}$ in the left margin next to each perception that describes you. 6. Teachers do not want to teach topics and issues associated with multicultural education.

$$
\text { 6. Reaction: }
$$

7. Teachers do not want the responsibility of ensuring equity for all students in their classrooms and schools. 7. Reaction:

Section II. Please write a response for question 8. Mark a large $\mathrm{X}$ in the appropriate columns for questions 9-12.

8. Grade level(s) and subject area(s) that you teach (write "all" if elementary school):

9. Years of teaching experience: $\quad 1-5 \quad 6-10 \quad 11-15 \quad 16-20$

$21-25$

$26-30$

$31+$

\begin{tabular}{|c|c|c|c|c|c|c|}
\hline 10. Your gender: & female & male & & & & \\
\hline 11. Your race/ethnicity: & $\begin{array}{l}\text { African- } \\
\text { American; } \\
\text { Black }\end{array}$ & $\begin{array}{l}\text { Asian- } \\
\text { American }\end{array}$ & $\begin{array}{l}\text { Caucasian; } \\
\text { White }\end{array}$ & $\begin{array}{l}\text { Hispanic; } \\
\text { Not } \\
\text { Caucasian }\end{array}$ & $\begin{array}{l}\text { Native } \\
\text { American }\end{array}$ & $\begin{array}{l}\text { Other; } \\
\text { Please } \\
\text { Identity }\end{array}$ \\
\hline 12. Your age group: & $18-24$ & $25-29$ & $30-39$ & $40-49$ & $50-59$ & $60+$ \\
\hline
\end{tabular}

